\title{
Sphingomonas oryziterrae sp. nov. and Sphingomonas jinjuensis sp. nov. isolated from rhizosphere soil of rice (Oryza sativa L.)
}

\begin{abstract}
Correspondence
Young Ryun Chung yrchung@gnu.ac.kr
\end{abstract}

\author{
Eu Jin Chung, ${ }^{1}$ Eun Ju Jo, ${ }^{2}$ Hwan Sik Yoon, ${ }^{2}$ Geun Cheol Song, ${ }^{2}$ \\ Che Ok Jeon ${ }^{3}$ and Young Ryun Chung ${ }^{2}$
}

\author{
${ }^{1}$ Department of Research and Development, JGreen Inc., Changnyeong 635-806, \\ Republic of Korea \\ ${ }^{2}$ Division of Applied Life Science (BK 21), Plant Molecular Biology and Biotechnology Research \\ Center, Gyeongsang National University, Jinju 660-701, Republic of Korea \\ ${ }^{3}$ Department of Life Sciences, Chung-Ang University, Seoul 156-756, Republic of Korea
}

Two Gram-reaction-negative, yellow-orange-pigmented, rod-shaped bacterial strains, designated $\mathrm{YC} 6722^{\top}$ and $\mathrm{YC} 6723^{\top}$, were isolated from rhizosphere soil samples collected from rice fields in Jinju, Korea. Strains $\mathrm{YC} 6722^{\top}$ and $\mathrm{YC} 6723^{\top}$ grew optimally at $25-30{ }^{\circ} \mathrm{C}$ and at $\mathrm{pH}$ 7.0-8.5. Phylogenetic analyses of 16S rRNA gene sequences showed that strain YC6722 ${ }^{\top}$ was most closely related to Sphingomonas jaspsi TDMA-16 ${ }^{\top}$ (96.6\% sequence similarity) and strain $\mathrm{YC6723}^{\mathrm{T}}$ was related most closely to Sphingomonas aquatilis JSS7 ${ }^{\top}$ ( $\left.96.9 \%\right)$. The two strains contained ubiquinone-10 (Q-10) as the major respiratory quinone system and sym-homospermidine as the major polyamine. The $G+C$ contents of the genomic DNA of strains YC6722 ${ }^{\top}$ and $\mathrm{YC} 6723^{\top}$ were 63.3 and $61.0 \mathrm{~mol} \%$, respectively. The major fatty acid was $\mathrm{C}_{18: 1} \omega 7 \mathrm{c}$. The polar lipids detected in the two strains were phosphatidylethanolamine, phosphatidylglycerol, diphosphatidylglycerol, sphingoglycolipid,

phosphatidyldimethylethanolamine and other unknown lipids. On the basis of their phylogenetic positions, and their biochemical and phenotypic characteristics, strains $\mathrm{YC} 622^{\top}$ and $\mathrm{YC} 6723^{\top}$ represent two novel species of the genus Sphingomonas, for which the names Sphingomonas oryziterrae sp. nov. (=KCTC $22476^{\top}=$ DSM $\left.21455^{\top}\right)$ and Sphingomonas jinjuensis sp. nov. $\left(\right.$ KCTC $22477^{\top}=$ DSM $\left.21457^{\top}\right)$ are proposed.
The genus Sphingomonas in the family Sphingomonadaceae of the Gammaproteobacteria was first proposed by Yabuuchi et al. (1990) and has subsequently been reclassified into four genera, namely Sphingomonas, Sphingobium, Novosphingobium and Sphingopyxis (Takeuchi et al., 2001; Yabuuchi et al., 2002). Since 2009, eight recognized species of the genus Sphingomonas have been described, namely S. aestuarii (Roh et al., 2009), S. japonica (Romanenko et al., 2009), S. hankookensis (Yoon et al., 2009), S. sanxanigenens (Huang et al., 2009), S. changbaiensis (Zhang et al., 2010), S. histidinilytica (Nigam et al., 2010), S. rubra (Huo et al., 2010) and S. glacialis (Zhang et al., 2011).

During analysis of the bacterial community in two rice fields of Gyeongsang National University Farm (Daegok

The GenBank/EMBL/DDBJ accession numbers for the 16S rRNA gene sequences of strains $\mathrm{YC} 6722^{\top}$ and $\mathrm{YC} 6723^{\top}$ are EU707560 and EU707561, respectively.

Three supplementary figures and one supplementary table are available with the online version of this paper.
Valley), north-east Jinju, Korea, managed under conventional and no-tillage practices, soil samples from the rhizosphere were collected from each field in 2007. Samples were sonicated in a Bandelin Sonoplus electronic homogenizer at $260 \mathrm{~W} \mathrm{~cm}^{-2}$ for $15 \mathrm{~s}$ and then serially diluted extracts, made by adding $50 \mathrm{mM}$ phosphate buffer ( $\mathrm{pH}$ 7.0) solution, were spread on modified half-strength R2A agar plates (Aslam et al., 2009; Janssen et al., 2002) and incubated at $28{ }^{\circ} \mathrm{C}$ for more than 1 month. Single colonies on the plates were purified by transferring them to new plates while keeping other conditions unchanged. Two novel Sphingomonas-like strains, designated $\mathrm{YC} 622^{\mathrm{T}}$ and $\mathrm{YC} 623^{\mathrm{T}}$, were isolated and characterized in this study.

Cell morphology was observed under a Nikon light microscope at $1000 \times$ magnification and the presence of flagella was investigated using a transmission electron microscope (model H-600, Hitachi) with cells grown at $30{ }^{\circ} \mathrm{C}$ for $72 \mathrm{~h}$ in $\mathrm{R} 2 \mathrm{~A}$ broth. The Gram reaction was determined by using a bioMérieux Gram stain kit according to the manufacturer's instructions. Catalase 
and oxidase tests were performed according to the procedures outlined in Cappuccino \& Sherman (2002). Tests for hydrolysis of casein, aesculin, gelatin, starch, L-tyrosine, urea and Tweens 20 and 80 by strains $\mathrm{YC}^{2} 622^{\mathrm{T}}$ and $\mathrm{YC} 6723^{\mathrm{T}}$ and the type strains of related species, including Sphingomonas astaxanthinifaciens TDMA-17 ${ }^{\mathrm{T}}$, S. kaistensis $\mathrm{PB} 56^{\mathrm{T}}$, S. abaci $\mathrm{C} 42^{\mathrm{T}}$, S. jaspsi TDMA- $16^{\mathrm{T}}$, S. faeni MA-olki ${ }^{\mathrm{T}}$, S. aquatilis $\mathrm{JSS7}^{\mathrm{T}}$, S. melonis DAPPPG224 ${ }^{\mathrm{T}}$, S. phyllosphaerae LMG $21958^{\mathrm{T}}$, S. yunnanensis YIM $003^{\mathrm{T}}$ and S. adhaesiva GIFU $11458^{\mathrm{T}}$ (Yabuuchi et al., 1990; Lee et al., 2001; Buonaurio et al., 2002; Busse et al., 2003, 2005; Rivas et al., 2004; Zhang et al., 2005; Asker et al., 2007a, b; Kim et al., 2007), were performed by using standard protocols (Brown, 2007; Atlas, 1993). Enzyme activities, acid production from different carbohydrates, assimilation of various substrates and growth on carbohydrates were determined by using API ZYM, API $20 \mathrm{E}$, API $20 \mathrm{NE}$ and API $50 \mathrm{CH}$ kits, at $30{ }^{\circ} \mathrm{C}$, respectively, according to instructions of the manufacturer (bioMérieux). Growth at $4,10,15,20,26,30,35,40$ and $45^{\circ} \mathrm{C}$, and at $\mathrm{pH} 4.0$ 12.0 (at intervals of $0.5 \mathrm{pH}$ units) were assayed after 5 days of incubation on R2A agar. Growth on nutrient agar (NA), Luria-Bertani (LB) agar, Czapek-dox agar, MacConkey agar, 1/10-strength trypticase soy agar (TSA) and R2A agar was also evaluated at $30{ }^{\circ} \mathrm{C}$ after 5 days of incubation. All culture media were purchased from Difco. Growth under anaerobic conditions was determined on R2A agar plates at $30{ }^{\circ} \mathrm{C}$ for 5 days in an anaerobic Gaspak jar containing an atmosphere of $\mathrm{CO}_{2}$ (Gas-Pack System; Becton Dickinson). Salt tolerance was tested in R2A broth supplemented with $0-6 \%(\mathrm{w} / \mathrm{v}) \mathrm{NaCl}$ (at intervals of $0.5 \%$ ) after 5 days of incubation at $30{ }^{\circ} \mathrm{C}$. Duplicate antibiotic-sensitivity tests were performed with filter-paper discs (BD; diameter $8 \mathrm{~mm}$ ) containing ( $\mu \mathrm{g}$ per disc) ampicillin (10), chloramphenicol (30), penicillin (10), gentamicin (10), kanamycin (30), vancomycin (30), streptomycin (10), tetracycline (10) and rifampicin (10). The discs were placed on R2A plates spread with cell suspension and the plates were then incubated at $30{ }^{\circ} \mathrm{C}$ for 3 days. Almost all tests performed on strains $\mathrm{YC} 6722^{\mathrm{T}}$ and $\mathrm{YC} 6723^{\mathrm{T}}$ were also performed on the reference type strains listed above.

Cells of strains $\mathrm{YC} 6722^{\mathrm{T}}$ and $\mathrm{YC} 6723^{\mathrm{T}}$ were Gram-reactionnegative and formed smooth, convex, circular colonies that were $0.5-1.5 \mathrm{~mm}$ in diameter after $72 \mathrm{~h}$ of incubation at $30{ }^{\circ} \mathrm{C}$. Colonies of strains $\mathrm{YC} 6722^{\mathrm{T}}$ and $\mathrm{YC} 6723^{\mathrm{T}}$ were darkyellow and dark-orange, respectively. Cells of strain YC6722 ${ }^{\mathrm{T}}$ were non-motile rods $0.5-0.6 \times 0.9-1.0 \mu \mathrm{m}$, while cells of strain $\mathrm{YC} 6723^{\mathrm{T}}$ were non-motile rods $0.6-0.8 \times 1.4-$ $1.6 \mu \mathrm{m}$ (Supplementary Fig. S1, available in IJSEM Online). Cells of strains $\mathrm{YC} 6722^{\mathrm{T}}$ and $\mathrm{YC} 6723^{\mathrm{T}}$ occurred singly, in pairs and in clusters. Both strains grew well aerobically on 1/10-strength TSA agar as well as NA and R2A agar but grew slowly on LB agar. The physiological and biochemical characteristics of strains $\mathrm{YC} 6722^{\mathrm{T}}$ and $\mathrm{YC} 6723^{\mathrm{T}}$ are summarized in the species descriptions and a comparison of selective characteristics with the type strains of closely related species is given in Table 1 .
Genomic DNA of strains $\mathrm{YC} 6722^{\mathrm{T}}$ and $\mathrm{YC} 6723^{\mathrm{T}}$ was extracted by using a commercial genomic DNA extraction kit (Core Biosystem). The 16S rRNA gene was PCRamplified from the purified genomic DNA using primers 27F and 1492R (Lane, 1991). The PCR product was cloned into a TOPO TA vector (Invitrogen) and sequenced by GenoTech. The 16S rRNA gene sequence was compiled by using SeqMan software (DNASTAR) and the sequences of related taxa were obtained from the GenBank database. Multiple sequence alignments were performed using the CLUSTAL X program (Thompson et al., 1997). Gaps were edited by using the BioEdit program (Hall, 1999). Phylogenetic trees were reconstructed using the neighbour-joining method (Saitou \& Nei, 1987) in the program MEGA4, with bootstrap values based on 1000 replications (Tamura et al., 2007), and the maximum-likelihood algorithm in the PHYLIP version 3.6 program (Felsenstein, 2002). Pair-wise sequence similarity values between strains $\mathrm{YC} 722^{\mathrm{T}}$ and $\mathrm{YC} 623^{\mathrm{T}}$ and the type strains of related species were computed by using the EzTaxon server (Chun et al., 2007).

The 16S rRNA gene sequences of strains $\mathrm{YC} 6722^{\mathrm{T}}$ and $\mathrm{YC} 6723^{\mathrm{T}}$ were a continuous stretch of 1365 and $1375 \mathrm{nt}$, respectively, showing $93.9 \%$ sequence similarity to each other. Based on phylogenetic analysis of $16 \mathrm{~S}$ rRNA gene sequences, the closest relatives of strain $\mathrm{YC}^{2} 722^{\mathrm{T}}$ were S. jaspsi TDMA- $16^{\mathrm{T}}$ (96.6\% similarity), S. kaistensis $\mathrm{PB} 56^{\mathrm{T}}$ (96.2\%), S. astaxanthinifaciens TDMA-17 $7^{\mathrm{T}}(96.1 \%)$, S. faeni MA-olki ${ }^{\mathrm{T}}(94.7 \%)$ and S. abaci $\mathrm{C}^{\mathrm{T}}{ }^{\mathrm{T}}(94.0 \%)$, whereas the closest relatives of strain $\mathrm{YC} 6723^{\mathrm{T}}$ were S. aquatilis $\mathrm{JSS}^{\mathrm{T}}$ (96.9\%), S. melonis DAPP-PG $224^{\mathrm{T}}(96.8 \%)$, S. phyllosphaerae LMG $21958^{\mathrm{T}}$ (96.3\%), S. yunnanensis YIM $003^{\mathrm{T}}$ $(96.1 \%)$ and S. adhaesiva GIFU $11458^{\mathrm{T}}(95.0 \%)$. In the neighbour-joining phylogenetic tree, strains $\mathrm{YC} 6722^{\mathrm{T}}$ and $\mathrm{YC} 6723^{\mathrm{T}}$ grouped in clades with the type strains of their related species with 87 and $60 \%$ bootstrap support, respectively (Fig. 1). The topology of the phylogenetic tree based on the maximum-likelihood algorithm (Supplementary Fig. S2) also supported the suggestion that strains YC6722 $2^{\mathrm{T}}$ and $\mathrm{YC} 6723^{\mathrm{T}}$ represent novel species within the genus Sphingomonas.

The cellular fatty acids of strains $\mathrm{YC} 6722^{\mathrm{T}}$ and $\mathrm{YC} 6723^{\mathrm{T}}$ and related type strains were analysed by using cells harvested from the third quadrant grown on R2A agar at $30{ }^{\circ} \mathrm{C}$ for $72 \mathrm{~h}$. Analysis of fatty acid methyl esters was performed according to the instructions of the Microbial Identification System (MIDI). Isoprenoid quinones were extracted and analysed by using reversed-phase HPLC according to the method described by Komagata \& Suzuki (1987). Polyamines were analysed as described by Busse \& Auling (1988) and Busse et al. (1997). For measurement of the $\mathrm{G}+\mathrm{C}$ content of the chromosomal DNA, genomic DNA was extracted and purified as described by Ausubel et al. (1995). This was then degraded enzymically into nucleosides and the $\mathrm{G}+\mathrm{C}$ content was determined as described by Mesbah et al. (1989) via reversed-phase HPLC. Polar lipids were extracted according to a 
Table 1. Differential phenotypic characteristics between strains $\mathrm{YC} 622^{\top}$ and $\mathrm{YC} 6723^{\top}$ and the type strains of closely related species of the genus Sphingomonas

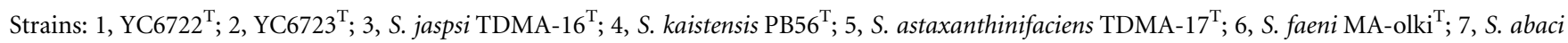
C42 $2^{\mathrm{T}}$; 8, S. aquatilis JSS7 ${ }^{\mathrm{T}}$; 9, S. melonis DAPP-PG 224 ${ }^{\mathrm{T}}$; 10, S. phyllosphaerae LMG 21958 ${ }^{\mathrm{T}}$; 11, S. yunnanensis YIM $003^{\mathrm{T}}$; 12 , S. adhaesiva GIFU $11458^{\mathrm{T}}$. +, Positive; -, negative; (+), weakly positive; ND, not determined; Y, yellow; D-Y, dark-yellow; L-Y, light-yellow; L-O, light-orange; D-O, dark-orange; $\mathrm{R}-\mathrm{O}$, red-orange. Data for the reference type strains are from this study unless indicated otherwise.

\begin{tabular}{|c|c|c|c|c|c|c|c|c|c|c|c|c|}
\hline Characteristic & 1 & 2 & 3 & 4 & 5 & 6 & 7 & 8 & 9 & 10 & 11 & 12 \\
\hline Motility* & - & - & + & - & + & + & - & + & - & + & + & + \\
\hline Growth with $3.0 \% \mathrm{NaCl}$ & - & - & - & - & + & - & - & - & - & - & - & + \\
\hline \multicolumn{13}{|l|}{ Hydrolysis of: } \\
\hline L-Tyrosine & - & + & - & - & - & - & + & + & + & + & - & + \\
\hline \multicolumn{13}{|l|}{ Enzyme activity } \\
\hline Cystine arylamidase & - & - & + & - & + & - & + & + & + & - & - & - \\
\hline Alkaline phosphatase & - & + & + & + & + & + & + & + & + & + & + & + \\
\hline $\begin{array}{l}\text { Naphthol-AS-BI- } \\
\text { phosphohydrolase }\end{array}$ & - & - & + & + & - & + & + & + & + & + & - & + \\
\hline Valine arylamidase & - & + & + & - & + & + & + & + & + & + & + & - \\
\hline D-Mannose & - & - & - & - & - & - & - & + & + & - & + & + \\
\hline Maltose & - & - & - & - & - & - & - & + & + & $(+)$ & $(+)$ & - \\
\hline Cellobiose & - & + & + & - & - & - & + & + & + & + & + & + \\
\hline Glycogen & + & - & - & - & - & - & - & - & - & - & - & - \\
\hline D-Xylose & - & - & - & - & - & - & + & + & + & + & + & - \\
\hline Aesculin ferric citrate & + & + & - & - & - & + & + & - & + & + & + & + \\
\hline DNA G $+\mathrm{C}$ content $(\mathrm{mol} \%)^{*}$ & 63.3 & 61.0 & 63.3 & $69.1-69.9$ & 67.7 & 63.1 & $\mathrm{ND}$ & 63.0 & 65.0 & 61.0 & 67.5 & 67.2 \\
\hline
\end{tabular}

${ }^{\star}$ Data for 3-12 are from Asker et al. (2007a), Kim et al. (2007), Asker et al. (2007b), Busse et al. (2003), Busse et al. (2005), Lee et al. (2001), Buonaurio et al. (2002), Rivas et al. (2004), Zhang et al. (2005) and Yabuuchi et al. (1990), respectively.

modification of the method of Minnikin et al. (1977) and were separated by TLC on a Merck Kieselgel 60-HPTLC. For two-dimensional TLC development, a chloroform, methanol and water $(65: 25: 4, \mathrm{v} / \mathrm{v} / \mathrm{v})$ mixture followed by a chloroform, methanol, acetic acid and water $(80: 12: 15: 4$, $\mathrm{v} / \mathrm{v} / \mathrm{v} / \mathrm{v})$ mixture were used as mobile phase. Aminolipids were detected by spraying the plate with a $0.2 \%(\mathrm{w} / \mathrm{v})$ solution of ninhydrin in butanol saturated with water followed by heating at $105{ }^{\circ} \mathrm{C}$ for $10 \mathrm{~min}$ (Ross et al., 1985). Phospholipids were detected by spraying the plate with Zinzadze reagent (Dittmer \& Lester, 1964). Glycolipids were detected with $0.5 \% 1$-naphthol in methanol/water $(1: 1, \mathrm{v} /$ v) and sulfuric acid/ethanol $(1: 1, \mathrm{v} / \mathrm{v})$, followed by heating at $120{ }^{\circ} \mathrm{C}$ for $5-10 \mathrm{~min}$ (Xin et al., 2000). The presence of phosphatidylcholine was detected with Dragendorff reagent (Sigma-Aldrich). Total lipid profiles were detected by spraying with phosphomolybdic acid solution (SigmaAldrich) followed by heating at $150{ }^{\circ} \mathrm{C}$.

Cellular fatty acid profiles of strains $\mathrm{YC} 6722^{\mathrm{T}}$ and $\mathrm{YC} 6723^{\mathrm{T}}$ and of the type strains of related species are shown in
Supplementary Table S1. The major fatty acids of strain $\mathrm{YC} 622^{\mathrm{T}}$ were $\mathrm{C}_{18: 1} \omega 7 c(26.3 \%)$, summed feature 3 $\left(\mathrm{C}_{16: 1} \omega 7 c\right.$ and/or iso- $\left.\mathrm{C}_{15: 0} 2-\mathrm{OH}\right)(23.0 \%)$ and $\mathrm{C}_{16: 0}$ $(21.3 \%)$, which are shared with the majority of members of the genus Sphingomonas. Similarly, the predominant fatty acids of strain $\mathrm{YC} 6723^{\mathrm{T}}$ were $\mathrm{C}_{18: 1} \omega 7 c(49.5 \%), \mathrm{C}_{14: 0}$ $2-\mathrm{OH}(17.4 \%)$ and summed feature $3(12.8 \%)$. The total fatty acid profiles were consistent with those of members of the family Sphingomonadaceae, displaying the presence of 2-hydroxy fatty acids and a lack of 3-hydroxy fatty acids. However, the total fatty acid profiles of strains $\mathrm{YC} 6722^{\mathrm{T}}$ and $\mathrm{YC} 6723^{\mathrm{T}}$ differed from those of representatives of the genus Sphingomonas both qualitatively and quantitatively (Busse et al., 1999; Takeuchi \& Hiraishi, 2001; Takeuchi et al., 2001). The major isoprenoid quinone of strains $\mathrm{YC} 6722^{\mathrm{T}}$ and $\mathrm{YC} 6723^{\mathrm{T}}$ was ubiquinone Q-10, consistent with data for the type strains of recognized species of the genus Sphingomonas (Busse et al., 1999; Yabuuchi et al., 1990; Yoon et al., 2006). The DNA G + C content of strains $\mathrm{YC} 622^{\mathrm{T}}$ and $\mathrm{YC} 6723^{\mathrm{T}}$ was 63.3 and $61.0 \mathrm{~mol} \%$, respectively; these values closely resembled those of recognized 


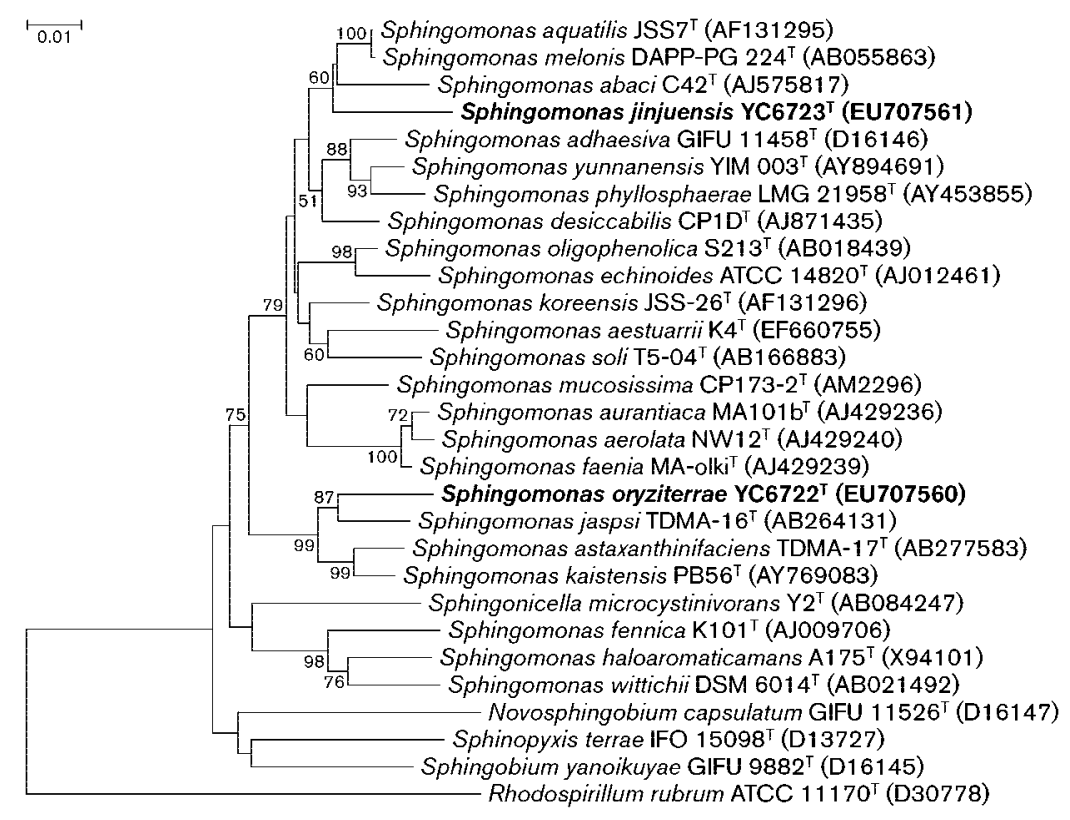

Fig. 1. Phylogenetic tree reconstructed from comparative analysis of $16 \mathrm{~S}$ rRNA gene sequences showing the relationship of strains YC6722 ${ }^{\top}$ and $Y_{C 6} 623^{\top}$ with the type strains of related species. The phylogenetic tree was reconstructed by using the neighbour-joining method and Jukes-Cantor evolutionary distance matrix data obtained from aligned nucleotides. Bootstrap values $>50 \%$ (based on 1000 replications) are shown at branch points. Bar, 0.01 substitutions per nucleotide position. species of the genus Sphingomonas (Asker et al., 2007a; Rivas et al., 2004; Yabuuchi et al., 2002). The polyamine patterns of the two strains comprised sym-homospermidine and minor amounts of spermidine, which was in agreement with those of members of the genus Sphingomonas (Huang et al., 2009; Roh et al., 2009; Busse et al., 2005). The polar lipid profiles of strains $\mathrm{YC} 6722^{\mathrm{T}}$ and $\mathrm{YC} 6723^{\mathrm{T}}$ were characterized by the presence of phosphatidylethanolamine, phosphatidylglycerol, diphosphatidylglycerol, sphingoglycolipid and phosphatidyldimethylethanolamine, which is in accordance with data for the genus Sphingomonas (Busse et al., 1999). Although the polar lipid profiles of strains $\mathrm{YC} 622^{\mathrm{T}}$ and $\mathrm{YC} 623^{\mathrm{T}}$ were similar, they differed in terms of their phosphoglycolipid content. Three unknown phosphoglycolipids (PGL1, PGL2 and PGL5) and three unknown lipids (L1, L2 and L3) were detected in strain $\mathrm{YC} 622^{\mathrm{T}}$ while three other unknown phosphoglycolipids (PGL3, PGL4 and PGL6) were detected in strain $\mathrm{YC6723}^{\mathrm{T}}$ (Supplementary Fig. S3).

On the basis of phylogenetic analyses (Fig. 1 and Supplementary Fig. S2), physiological and biochemical characteristics (Table 1), polyamine patterns, polar lipid analyses (Supplementary Fig. S3) and fatty acid profiles (Supplementary Table S1), strains YC6722 ${ }^{\mathrm{T}}$ and $\mathrm{YC}^{\mathrm{C}} 623^{\mathrm{T}}$ represent two novel species of the genus Sphingomonas, for which the names Sphingomonas oryziterrae sp. nov. and Sphingomonas jinjuensis sp. nov. are proposed, respectively.

\section{Description of Sphingomonas oryziterrae sp. nov.}

Sphingomonas oryziterrae (o.ry.zi.ter'ra.e. L. n. oryza rice; L. n. terra earth, soil; N.L. gen. n. oryziterrae of rice soil or field, referring to the source of isolation of the type strain).
Cells are Gram-reaction-negative, aerobic, non-motile short rods, $0.5-0.6 \times 0.9-1.0 \mu \mathrm{m}$. Colonies grown on R2A agar at $30{ }^{\circ} \mathrm{C}$ for 3 days are $0.5-1.0 \mathrm{~mm}$ in diameter, dark-yellow, smooth, convex and circular. Grows on R2A agar, NA, LB agar and 1/10-strength TSA (Difco) at $30{ }^{\circ} \mathrm{C}$ but not on MacConkey agar or Czapek-dox agar. Oxidase-positive and catalase-negative. Grows at $20-40{ }^{\circ} \mathrm{C}$ (optimum $25-30{ }^{\circ} \mathrm{C}$ ) and $\mathrm{pH}$ 6.0-10.5 (optimum $\mathrm{pH} 8-8.5$ ). Optimal growth occurs in the absence of $\mathrm{NaCl}$. Sensitive to ( $\mu$ g per disk) ampicillin (10), chloramphenicol (30), erythromycin (15), oleandomycin (15) and streptomycin (10) but resistant to penicillin (10), gentamicin (10), kanamycin (30), vancomycin (30), tetracycline (10) and rifampicin (10). Hydrolyses aesculin but not casein, Tweens 20 or 80, L-tyrosine, starch, gelatin or urea. Nitrate is not reduced to nitrite or nitrogen. Positive in tests for activity of $\alpha$-glucosidase but not for alkaline phosphatase, valine arylamidase, cystine arylamidase, naphthol-AS-BI-phosphohydrolase, $\beta$-galactosidase or $\alpha$-glucosidase activities. Utilizes D-glucose, aesculin ferric citrate, maltose, starch and glycogen as sole carbon sources but not cellobiose, gentiobiose, lactose, L-arabinose, melibiose, D-fructose, D-galactose, D-mannose, D-mannitol or $\mathrm{D}$-glucose. The major isoprenoid quinone is ubiquinone $\mathrm{Q}-10$. The major polyamine is sym-homospermidine. The polar lipid profile comprises phosphatidylethanolamine, phosphatidylglycerol, diphosphatidylglycerol, sphingoglycolipid, phosphatidyldimethylethanolamine, three unknown phosphoglycolipids (PGL1, PGL2 and PGL5) and three unknown lipids (L1, L2 and L3). The major fatty acids are $\mathrm{C}_{18: 1} \omega 7 c$, summed feature $3\left(\mathrm{C}_{16: 1} \omega 7 c\right.$ and/or iso- $\mathrm{C}_{15: 0}$ 2-OH) and $\mathrm{C}_{16: 0}$.

The type strain, YC6722 ${ }^{\mathrm{T}}$ (=KCTC $22476^{\mathrm{T}}=\mathrm{DSM}$ $21455^{\mathrm{T}}$ ), was isolated from the rhizosphere of a rice field managed under no-tillage in Jinju, Korea. The DNA G + C content of the type strain is $63.3 \mathrm{~mol} \%$. 


\section{Description of Sphingomonas jinjuensis sp. nov.}

Sphingomonas jinjuensis (jin.ju.en'sis. N.L. adj. jinjuensis referring to the Jinju Region of Korea, from where the type strain was found).

Cells are Gram-reaction-negative, aerobic, non-motile rods, $0.6-0.8 \times 1.4-1.6 \mu \mathrm{m}$. Colonies grown on R2A agar at $30{ }^{\circ} \mathrm{C}$ for 3 days are $1.0-1.5 \mathrm{~mm}$ in diameter, darkorange, smooth, convex and circular. Grows on R2A agar, $\mathrm{NA}$, LB agar and 1/10-strength TSA at $30{ }^{\circ} \mathrm{C}$ but not on MacConkey agar or Czapek-dox agar. Oxidase-negative and catalase-positive. Grows at $20-35{ }^{\circ} \mathrm{C}$ (optimum 25 $30{ }^{\circ} \mathrm{C}$ ) and $\mathrm{pH} \mathrm{5.0-10.5} \mathrm{(optimum} \mathrm{pH} \mathrm{7-8).} \mathrm{Optimal}$ growth occurs in the absence of $\mathrm{NaCl}$. Sensitive to $(\mu \mathrm{g}$ per disc) ampicillin (10), chloramphenicol (30), erythromycin (15), oleandomycin (15), gentamicin (10), kanamycin (30), vancomycin (30) and streptomycin (10) but resistant to penicillin (10), tetracycline (10) and rifampicin (10). Hydrolyses Tween 20, L-tyrosine, aesculin and urea but not casein, Tween 80 , starch or gelatin. Nitrate is not reduced to nitrite or nitrogen. Positive in tests for activities of $\alpha$-chymotrypsin, $\alpha$-galactosidase and $\alpha$-glucosidase, but not for esterase lipase (C8), cystine arylamidase, naphtholAS-BI-phosphohydrolase or $\beta$-glucuronidase. Utilizes glycerol, L-rhamnose, melibiose, trehalose, melezitose, raffinose, starch and turanose as sole carbon sources but not D-xylose, D-mannitol, arbutin or salicin. Assimilates 4nitrophenyl- $\beta$-D-galactopyranoside, but not glucose, arabinose, mannose, maltose, caprate or $\mathrm{N}$-acetylglucosamine. The major isoprenoid quinone is ubiquinone Q-10. The major polyamine is sym-homospermidine. The polar lipid profile comprises phosphatidylethanolamine, phosphatidylglycerol, diphosphatidylglycerol, sphingoglycolipid, phosphatidyldimethylethanolamine, four unknown phosphoglycolipids (PGL3, PGL4, PGL5 and PGL6) and two unknown lipids (L1 and L2). The major fatty acids are $\mathrm{C}_{18: 1} \omega 7 c, \mathrm{C}_{14: 0} 2-\mathrm{OH}$ and summed feature $3\left(\mathrm{C}_{16: 1} \omega 7 c\right.$ and/or iso- $\left.\mathrm{C}_{15: 0} 2-\mathrm{OH}\right)$.

The type strain, YC6723 ${ }^{\mathrm{T}}\left(=\mathrm{KCTC} 22477^{\mathrm{T}}=\mathrm{DSM}\right.$ $\left.21457^{\mathrm{T}}\right)$, was isolated from the rhizosphere of a rice field managed under conventional practice in Jinju, Korea. The DNA $\mathrm{G}+\mathrm{C}$ content of the type strain is $61.0 \mathrm{~mol} \%$.

\section{Acknowledgements}

This work was supported by a Brain Korea (BK) 21 project in 2008/ 2009 run by the Ministry of Education, Science and Technology, Korea and was partially supported by a grant of research and business development run by the Ministry of Food, Agriculture, Forestry and Fisheries, (no. 808015-3), Korea.

\section{References}

Asker, D., Beppu, T. \& Ueda, K. (2007a). Sphingomonas jaspsi sp. nov., a novel carotenoid-producing bacterium isolated from Misasa, Tottori, Japan. Int J Syst Evol Microbiol 57, 1435-1441.

Asker, D., Beppu, T. \& Ueda, K. (2007b). Sphingomonas astaxanthinifaciens sp. nov., a novel astaxanthin-producing bacterium of the family Sphingomonadaceae isolated from Misasa, Tottori, Japan. FEMS Microbiol Lett 273, 140-148.

Aslam, Z., Yasir, M., Jeon, C. O. \& Chung, Y. R. (2009). Lysobacter oryzae sp. nov., isolated from the rhizosphere of rice (Oryza sativa L.). Int J Syst Evol Microbiol 59, 675-680.

Atlas, R. M. (1993). Handbook of Microbiological Media. Edited by L. C. Parks. Boca Raton, FL: CRC Press.

Ausubel, F. W., Brent, R., Kingston, R. E., Moore, D. D., Seidman, J. G., Smith, J. A. \& Struhl, K. (1995). Current Protocols in Molecular Biology. New York: Wiley.

Brown, A. E. (2007). Benson's Microbiological Applications: Laboratory Manual in General Microbiology. New York: McGraw-Hill.

Buonaurio, R., Stravato, V. M., Kosako, Y., Fujiwara, N., Naka, T., Kobayashi, K., Cappelli, C. \& Yabuuchi, E. (2002). Sphingomonas melonis sp. nov., a novel pathogen that causes brown spots on yellow Spanish melon fruits. Int J Syst Evol Microbiol 52, 2081-2087.

Busse, H.-J. \& Auling, G. (1988). Polyamine pattern as a chemotaxonomic marker within the Proteobacteria. Syst Appl Microbiol 11, 1-8.

Busse, H. J., Bunka, S., Hensel, A. \& Lubitz, W. (1997). Discrimination of members of the family Pasteurellaceae based on polyamine patterns. Int J Syst Bacteriol 47, 698-708.

Busse, H. J., Kämpfer, P. \& Denner, E. B. (1999). Chemotaxonomic characterisation of Sphingomonas. J Ind Microbiol Biotechnol 23, 242-251.

Busse, H. J., Denner, E. B. M., Buczolits, S., Salkinoja-Salonen, M., Bennasar, A. \& Kämpfer, P. (2003). Sphingomonas aurantiaca sp. nov., Sphingomonas aerolata sp. nov. and Sphingomonas faeni sp. nov., air- and dustborne and Antarctic, orange-pigmented, psychrotolerant bacteria, and emended description of the genus Sphingomonas. Int J Syst Evol Microbiol 53, 1253-1260.

Busse, H. J., Hauser, E. \& Kämpfer, P. (2005). Description of two novel species, Sphingomonas abaci sp. nov. and Sphingomonas panni sp. nov. Int J Syst Evol Microbiol 55, 2565-2569.

Cappuccino, J. G. \& Sherman, N. (2002). Microbiology: a Laboratory Manual, 6th edn. Menlo Park, CA: Benjamin/Cummings.

Chun, J., Lee, J. H., Jung, Y., Kim, M., Kim, S., Kim, B. K. \& Lim, Y. W. (2007). EzTaxon: a web-based tool for the identification of prokaryotes based on 16S ribosomal RNA gene sequences. Int J Syst Evol Microbiol 57, 2259-2261.

Dittmer, J. C. \& Lester, R. L. (1964). A simple, specific spray for the detection of phospholipids on thin-layer chromatograms. J Lipid Res 15, 126-127.

Felsenstein, J. (2002). PHYLIP (phylogeny inference package), version 3.6a. Distributed by the author. Department of Genome Sciences, University of Washington, Seattle, USA.

Hall, T. A. (1999). BioEdit: a user-friendly biological sequence alignment editor and analysis program for Windows 95/98/NT. Nucleic Acids Symp Ser 41, 95-98.

Huang, H. D., Wang, W., Ma, T., Li, G. Q., Liang, F. L. \& Liu, R. L. (2009). Sphingomonas sanxanigenens sp. nov., isolated from soil. Int J Syst Evol Microbiol 59, 719-723.

Huo, Y. Y., Xu, X. W., Liu, S. P., Cui, H. L., Li, X. \& Wu, M. (2010). Sphingomonas rubra sp. nov., isolated from wastewater in a bioreactor. Int J Syst Evol Microbiol 61, 1028-1032.

Janssen, P. H., Yates, P. S., Grinton, B. E., Taylor, P. M. \& Sait, M. (2002). Improved culturability of soil bacteria and isolation in pure culture of novel members of the divisions Acidobacteria, Actinobacteria, Proteobacteria, and Verrucomicrobia. Appl Environ Microbiol 68, 2391-2396.

Kim, M. K., Schubert, K., Im, W. T., Kim, K. H., Lee, S. T. \& Overmann, J. (2007). Sphingomonas kaistensis sp. nov., a novel 
alphaproteobacterium containing pufLM genes. Int J Syst Evol Microbiol 57, 1527-1534.

Komagata, K. \& Suzuki, K. (1987). Lipid and cell-wall analysis in bacterial systematics. Methods Microbiol 19, 161-207.

Lane, D. J. (1991). 16S/23S rRNA sequencing. In Nucleic Acid Techniques in Bacterial Systematics, pp. 115-175. Edited by E. Stackebrandt \& M. Goodfellow. Chichester: Wiley.

Lee, J. S., Shin, Y. K., Yoon, J. H., Takeuchi, M., Pyun, Y. R. \& Park, Y. H. (2001). Sphingomonas aquatilis sp. nov., Sphingomonas koreensis sp. nov., and Sphingomonas taejonensis sp. nov., yellow-pigmented bacteria isolated from natural mineral water. Int J Syst Evol Microbiol 51, 14911498.

Mesbah, M., Premachandran, U. \& Whitman, W. B. (1989). Precise measurement of the $\mathrm{G}+\mathrm{C}$ content of deoxyribonucleic acid by highperformance liquid chromatography. Int J Syst Bacteriol 39, 159-167.

Minnikin, D. E., Patel, P. V., Alshamaony, L. \& Goodfellow, M. (1977). Polar lipid composition in the classification of Nocardia and related bacteria. Int J Syst Bacteriol 27, 104-117.

Nigam, A., Jit, S. \& Lal, R. (2010). Sphingomonas histidinilytica sp. nov., isolated from a hexachlorocyclohexane dump site. Int J Syst Evol Microbiol 60, 1038-1043.

Rivas, R., Abril, A., Trujillo, M. E. \& Velázquez, E. (2004). Sphingomonas phyllosphaerae sp. nov., from the phyllosphere of Acacia caven in Argentina. Int J Syst Evol Microbiol 54, 2147-2150.

Roh, S. W., Kim, K. H., Nam, Y. D., Chang, H. W., Kim, M. S., Oh, H. M. \& Bae, J. W. (2009). Sphingomonas aestuarii sp. nov., isolated from tidal flat sediment. Int J Syst Evol Microbiol 59, 1359-1363.

Romanenko, L. A., Tanaka, N., Frolova, G. M. \& Mikhailov, V. V. (2009). Sphingomonas japonica sp. nov., isolated from the marine crustacean Paralithodes camtschatica. Int J Syst Evol Microbiol 59, 1179-1182.

Ross, H. N. M., Grant, W. D. \& Harris, J. E. (1985). Lipids in archaebacterial taxonomy. In Chemical Methods in Bacterial Systematics, pp. 289-300. Edited by M. Goodfellow \& D. E. Minnikin. London: Academic Press.

Saitou, N. \& Nei, M. (1987). The neighbor-joining method: a new method for reconstructing phylogenetic trees. Mol Biol Evol 4, 406-425.

Takeuchi, M. \& Hiraishi, A. (2001). Taxonomic significance of 2-hydroxy fatty acid profiles of the species in the genus Sphingomonas and related taxa. Inst Ferment Res Commun (Osaka) 20, 72-82.

Takeuchi, M., Hamana, K. \& Hiraishi, A. (2001). Proposal of the genus Sphingomonas sensu stricto and three new genera, Sphingobium,
Novosphingobium and Sphingopyxis, on the basis of phylogenetic and chemotaxonomic analyses. Int J Syst Evol Microbiol 51, 1405-1417.

Tamura, K., Dudley, J., Nei, M. \& Kumar, S. (2007). MEGA4: molecular evolutionary genetics analysis (MEGA) software version 4.0. Mol Biol Evol 24, 1596-1599.

Thompson, J. D., Gibson, T. J., Plewniak, F., Jeanmougin, F. \& Higgins, D. G. (1997). The CLUSTAL_X windows interface: flexible strategies for multiple sequence alignment aided by quality analysis tools. Nucleic Acids Res 25, 4876-4882.

Xin, H., Itoh, T., Zhou, P., Suzuki, K., Kamekura, M. \& Nakase, T. (2000). Natrinema versiforme sp. nov., an extremely halophilic archaeon from Aibi salt lake, Xinjiang, China. Int J Syst Evol Microbiol 50, 1297-1303.

Yabuuchi, E., Yano, I., Oyaizu, H., Hashimoto, Y., Ezaki, T. \& Yamamoto, H. (1990). Proposals of Sphingomonas paucimobilis gen. nov. and comb. nov., Sphingomonas parapaucimobilis sp. nov., Sphingomonas yanoikuyae sp. nov., Sphingomonas adhaesiva sp. nov., Sphingomonas capsulata comb. nov., and two genospecies of the genus Sphingomonas. Microbiol Immunol 34, 99-119.

Yabuuchi, E., Kosako, Y., Fujiwara, N., Naka, T., Matsunaga, I., Ogura, H. \& Kobayashi, K. (2002). Emendation of the genus Sphingomonas Yabuuchi et al. 1990 and junior objective synonymy of the species of three genera, Sphingobium, Novosphingobium and Sphingopyxis, in conjunction with Blastomonas ursincola. Int J Syst Evol Microbiol 52, 1485-1496.

Yoon, J. H., Lee, M. H., Kang, S. J., Lee, S. Y. \& Oh, T. K. (2006). Sphingomonas dokdonensis sp. nov., isolated from soil. Int J Syst Evol Microbiol 56, 2165-2169.

Yoon, J. H., Park, S., Kang, S. J., Kim, W. \& Oh, T. K. (2009). Sphingomonas hankookensis sp. nov., isolated from wastewater. Int $J$ Syst Evol Microbiol 59, 2788-2793.

Zhang, Y. Q., Chen, Y. G., Li, W. J., Tian, X. P., Xu, L. H. \& Jiang, C. L. (2005). Sphingomonas yunnanensis sp. nov., a novel Gram-negative bacterium from a contaminated plate. Int J Syst Evol Microbiol 55, 2361-2364.

Zhang, J. Y., Liu, X. Y. \& Liu, S. J. (2010). Sphingomonas changbaiensis sp. nov., isolated from forest soil. Int J Syst Evol Microbiol 60, 790-795.

Zhang, D. C., Busse, H. J., Liu, H. C., Zhou, Y. G., Schinner, F. \& Margesin, R. (2011). Sphingomonas glacialis sp. nov., a psychrophilic bacterium isolated from alpine glacier cryoconite. Int J Syst Evol Microbiol 61, 587-591. 